\title{
Distribution of Pathotypes of Rhynchosporium secalis and Cultivar Reaction on Barley in Alberta
}

K. Xi, Alberta Agriculture, Food and Rural Development, 6000 C \& E Trail, Lacombe, AB T4L 1W1; T. K. Turkington, Agriculture and Agri-Food Canada, Lacombe Research Centre, $6000 \mathrm{C} \& \mathrm{E}$ Trail, Lacombe, AB T4L 1W1; J. H. Helm, Alberta Agriculture, Food and Rural Development, 503050 Street, Lacombe, AB T4L 1W8; K. G. Briggs and J. P. Tewari, Department of Agricultural, Food and Nutritional Science, University of Alberta, Edmonton, AB T6G 2P5; T. Ferguson, Agricore, 11111 Barlow Trail S.E., Calgary, AB T2C 4M5; and P. D. Kharbanda, Alberta Research Council, Vegreville, AB T9C 1T4

\begin{abstract}
Xi, K., Turkington, T. K., Helm, J. H., Briggs, K. G., Tewari, J. P., Ferguson, T., and Kharbanda, P. D. 2003. Distribution of pathotypes of Rhynchosporium secalis and cultivar reaction on barley in Alberta. Plant Dis. 87:391-396.

Forty-four barley accessions and commercial cultivars with different levels of resistance to scald caused by Rhynchosporium secalis were evaluated for scald reaction from 1997 to 1999 at various sites in Alberta. The accessions Hudson, Atlas, Atlas 46, Atlas 68, Abyssinian, and Kitchin that have the major resistance genes were resistant to pathotypes of $R$. secalis at all sites. Although scald levels were low for these accessions, they were significantly different among years. Pathotypes of $R$. secalis and environmental conditions affected diseases levels on 32 commercial cultivars, resulting in significantly different scald reactions among sites and seasons. Resistance in commercial cultivars, AC Stacy, Kasota, and Seebe, held up at most sites with the majority of cultivars being intermediate to moderately susceptible. Cultivars that were previously considered resistant were intermediate in reaction and became increasingly susceptible at some sites from 1997 to 1999. Pathogen virulence was more diverse at the sites where the cultivars became increasingly susceptible compared with sites where the same cultivars were resistant. Scald reactions of the commercial cultivars depended on location, which reflected the presence of different pathotypes, as well as variation in environmental conditions. Consequently, scald management via cultivar choice will be dependent on location.
\end{abstract}

Barley (Hordeum vulgare L.) production in Alberta averaged around 6 million metric tons from 2 million hectares annually from 1995 to 1999 , and accounted for nearly $50 \%$ of the total barley production in western Canada (2). Scald, caused by Rhynchosporium secalis J.J. Davis, is one of the major foliar diseases of barley in Alberta as a result of intensive production, and cool and wet environmental conditions that favor disease development (11). Yield losses due to scald are estimated to be 1 to $19 \%$ in field trials $(17,23)$, and losses as high as 20 to $36 \%$ have been reported (4). Average barley yield reductions can result in annual estimated monetary losses of approximately $\$ 7$ million in Alberta (21).

In Alberta, a shift in virulence of $R$. secalis populations has been evidenced by changes in cultivar reaction $(21,23)$. The

Corresponding author: K. Xi

E-mail: keguan.xi@gov.ab.ca

Accepted for publication 5 November 2003.

Publication no. D-2003-0217-01R

This article is in the public domain and not copyrightable. It may be freely reprinted with customary crediting of the source. The American Phytopathological Society, 2003. scald-resistant cultivars, CDC Guardian, CDC Richard, and TR129, showed less than $30 \%$ of the scald severity of the average of three susceptible cultivars, Argyle, Harrington, and Jackson, in a 1993 survey in Alberta (24). In later studies, these resistance cultivars frequently had 70 to $100 \%$ of the scald severity of the susceptible cultivars (23). The scald-resistant cultivar, CDC Guardian, showed 1, 26, and 70\% of the disease severity relative to the susceptible cultivar, Harrington, in field trials during 1993, 1995, and 1996, respectively. Yield losses of 1.6, 4.8, and $15.7 \%$ were observed in CDC Guardian in the same trials during 1993, 1995, and 1996, respectively (23). These observations indicate that shifts in the virulence of $R$. secalis and the potential for high variability in the virulence of the scald pathogen were responsible for the observed breakdown of barley cultivar resistance in Alberta.

Planting resistant cultivars is one of the major methods for control of scald of barley, but successful control using resistance depends on a clear understanding of the interaction between host and pathogen. Knowledge about variation in the virulence of pathotypes of $R$. secalis is important for breeding programs that are attempting to incorporate scald resistance, so breeders can deploy sources of resistance that are likely to be effective against the range of pathotypes in a given area. Variation in the virulence of $R$. secalis among locations may be exploited by the deployment of cultivars with diverse sources of scald resistance.

The current status of scald resistance in commercial barley cultivars in relation to the distribution of pathotypes of $R$. secalis needs to be clarified. The objectives of this study were to evaluate the scald reaction of commercially available cultivars in relation to spatial and temporal patterns of scald distribution across the major barley production areas of Alberta, and to provide information on potential sources of resistance that are effective against the most prevalent pathotypes in Alberta.

\section{MATERIALS AND METHODS}

Hill plots were established at Edmonton $\left(53^{\circ} 34^{\prime} \mathrm{N}, 113^{\circ} 31^{\prime} \mathrm{W}\right), \quad$ Beaverlodge $\left(55^{\circ} 13^{\prime} \mathrm{N}, 119^{\circ} 26^{\prime} \mathrm{W}\right)$, Calmar (53ำ $16^{\prime} \mathrm{N}$, $\left.113^{\circ} 49^{\prime} \mathrm{W}\right)$, Carstairs $\left(51^{\circ} 34^{\prime} \mathrm{N}, 114^{\circ} 06^{\prime}\right.$ W), Lacombe $\left(52^{\circ} 28^{\prime} \mathrm{N}, 113^{\circ} 44^{\prime} \mathrm{W}\right)$, Stettler $\left(52^{\circ} 19^{\prime} \mathrm{N}, 112^{\circ} 43^{\prime} \mathrm{W}\right)$, Trochu $\left(51^{\circ} 50^{\prime}\right.$ $\left.\mathrm{N}, 113^{\circ} 13^{\prime} \mathrm{W}\right)$, Vegreville $\left(53^{\circ} 30^{\prime} \mathrm{N}\right.$, $\left.112^{\circ} 03^{\prime} \mathrm{W}\right)$, and Westlock $\left(54^{\circ} 09^{\prime} \mathrm{N}\right.$, $\left.113^{\circ} 52^{\prime} \mathrm{W}\right)$. Each of these trials included nine accessions and 35 commercial cultivars with different levels of scald resistance (Tables 1 and 2). The set of acces-

Table 1. Relative mean percentage of scald severity for barley accessions in 18 field trials in Alberta from 1997 to 1999

\begin{tabular}{lcc}
\hline Accession & CI no $^{\mathbf{x}}$ & $\begin{array}{c}\text { Disease } \\
\text { severity }(\boldsymbol{\%}) \mathbf{y}\end{array}$ \\
\hline Abyssinian & 668 & 32 \\
Atlas & 4118 & 37 \\
Atlas46 & 7323 & 29 \\
Atlas68 & 13824 & 38 \\
Hudson & 8067 & 4 \\
Kitchin & 1296 & 38 \\
Modoc & 7566 & 67 \\
Trebi & 936 & 68 \\
Turk & 14400 & 29
\end{tabular}

${ }^{\mathrm{x}}$ Accession number of Cereal Crops Research Branch, ARS, USDA, Beltsville, Maryland.

${ }^{y}$ Percent disease severity relative to the mean of three susceptible cultivars: Argyle, Harrington, and Jackson. The mean disease severity for the three susceptible cultivars, 6.0 on a scale of 0 to 9 , was considered $100 \%$. 
sions used (Table 1) have the major scald resistance genes $(19,20)$, and these genes have been used for pathotype differentiation in numerous studies $(9,19,22,26)$. Cultivar Atlas 68, an isogenic line of Atlas 46 (15), was used because it displayed differential scald reactions compared with Atlas 46 in previous tests. The commercial cultivars (Table 2) included two- and sixrow malt and feed barley types grown in western Canada. All accessions and cultivars were spring types except for Hudson, which is a winter barley. All trials, except for Edmonton in 1998, were established on land where scald of barley occurred in previous seasons to provide a natural source of inoculum. Each test was a randomized complete block design with four replicates for 1997 and 1998 and five replicates for 1999. Seeding was done by planting about 10 seeds to a hill plot with $0.5-\mathrm{m}$ spacing between hills and $1 \mathrm{~m}$ between replicates. At growth stage (GS) 4050 and GS 80-90 (27), disease severity was assessed visually using a 0 to 9 scale described by Couture (5) and Saari and Prescott (14). This scale assesses diseased leaf area at the bottom, middle, and upper levels of the canopy, where 0 is no disease and 9 represents a plant with greater than $50 \%$ of all three levels of the canopy diseased.

For each site and season, disease severity data using the 0 to 9 scale for the nine accessions and 32 commercial cultivars were converted to percentage of disease severity relative to the average of the three susceptible cultivars, Argyle, Harrington, and Jackson. An arcsine transformation was applied to equalize the variance of the percent data for relative disease severity. The transformed data of relative severity for the accessions and for the cultivars were analyzed separately, and analysis of variance was used to determine interactions between accession or cultivar, location, and year. The error variances from the individual experiments were examined for heterogeneity by comparing the ratio of the largest error variance to the smallest (13). This resulted in four homogeneous groups, accession group 1 and cultivar group 1 (Table 3), and accession group 2 and cultivar group 2 (Table 4), for analysis of variance. Analysis of the group 1 accessions or cultivars included year, location, cultivar or accession, and their interactions, while analysis of the group 2 accessions or cultivars included all effects except for year and its interaction effects. The year factor was not included in accession group 2 and cultivar group 2 because of the lack of replication within year. Accession or cultivar and location were considered fixed effects, while all other factors were considered to be random effects. Because of the mixed model for analysis and imbalanced data sets caused by excluding tests with heterogeneous variances, SAS GLM Type IV sums of squares were used for the analyses (1989, SAS Institute, Cary, NC). The TEST option in the RANDOM statement of the SAS GLM procedure was used

Table 2. Mean percentage of scald severity for 32 commercial barley cultivars relative to the mean of three susceptible cultivars, Argyle, Harrington, and Jackson, in 18 field trials, Alberta, 1997 to 1999

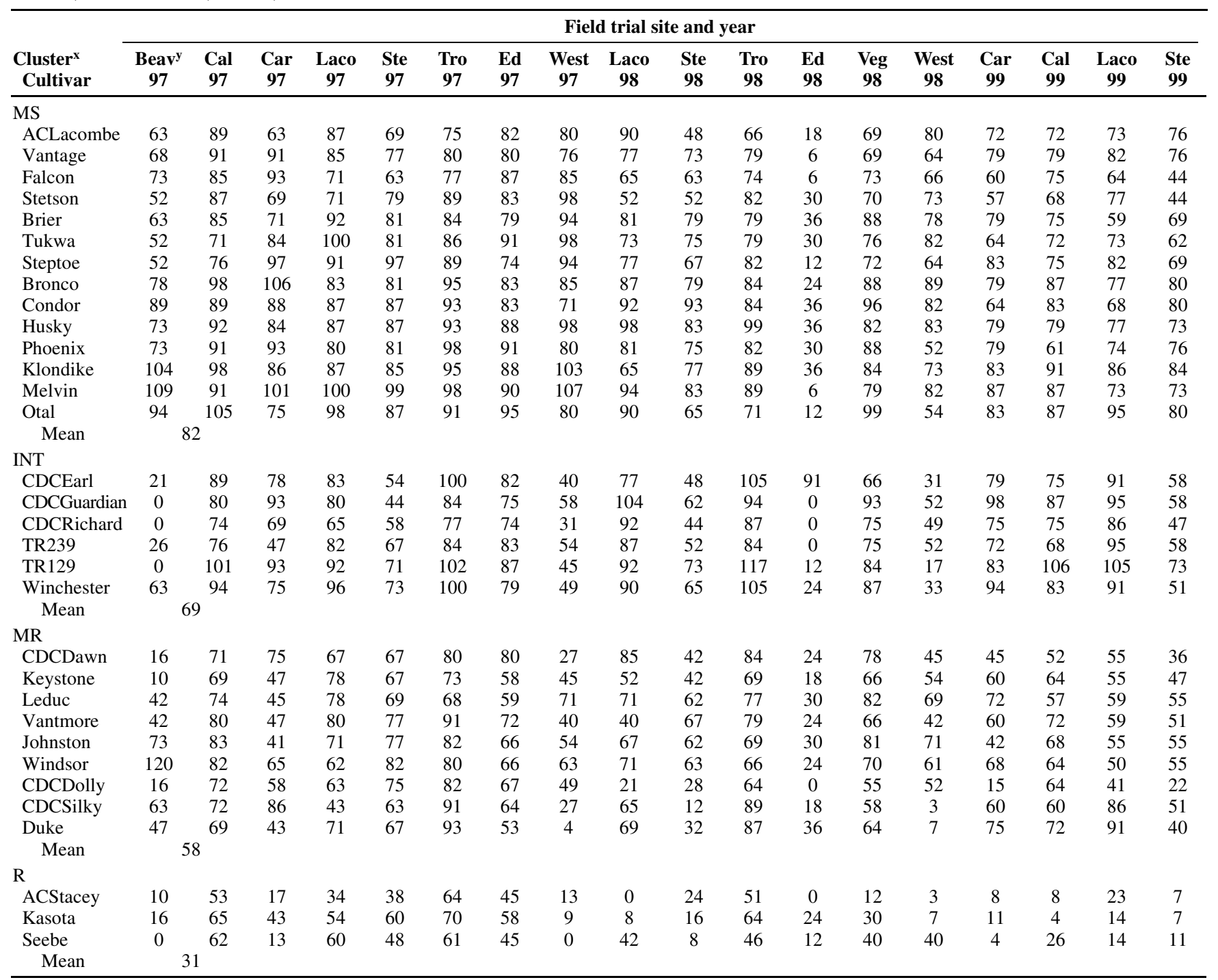

$\overline{\mathrm{x}} \mathrm{MS}=$ moderately susceptible; $\mathrm{INT}=$ intermediate; $\mathrm{MR}=$ moderately resistant; $\mathrm{R}=$ resistant.

${ }^{\mathrm{y}}$ Beav $=$ Beaverlodge; $\mathrm{Cal}=$ Calmar; Car $=$ Carstairs; Laco $=$ Lacombe; Ste $=$ Stettler; Tro $=$ Trochu; Ed $=$ Edmonton; Veg $=$ Vegreville; West $=$ Westlock. 
to calculate $F$ tests for each effect based on an appropriate error term. A complete linkage method of cluster analysis using the Statistical Analysis System (SAS Institute) was carried out to classify the different responses of the 32 commercial cultivars to the scald pathogen as measured by Euclidean distance between the responses (7). This classification of cultivar reactions was used to determine if resistance had been overcome as a result of new virulent pathotypes on resistant cultivars, as evidenced by an increase in disease severity at particular sites or seasons.

The phenotypic diversity of the scald pathogen based on the reactions of 32 commercial cultivars was estimated by Shannon's information statistic (28) as

$$
\begin{aligned}
& \text { Ho }=-\sum_{j}\left(f i j / \sum_{j} f i j\right) \ln \left(f i j / \sum_{j} f i j\right) \\
& \text { for all } j=0,1 \ldots 9
\end{aligned}
$$

where $f i j$ is the score of disease severity in the $j$ th category from 0 to 9 for $i$ th cultivar. $H_{s y}$ was the mean of the phenotypic diversity (Ho) over all cultivars at each site and season.

\section{RESULTS}

The first assessment at GS 40-50 had low disease severity ( 1 to 3 based on the 0 to 9 scale); however, significant levels of disease were observed by the second assessment date at GS 80-90. In the second assessment, the average severity level was greater than 4.4 for the mean rating for the three susceptible cultivars, which was adequate to differentiate accession and cultivar reactions and indicated sites where environmental conditions were conducive for scald development. A rating of 4.4 was the minimum level set (Table 5) to arbitrarily select tests for analyses. As a result, analyses were based on the second assessment date from eight sites in 1997, six sites in 1998, and four sites in 1999, with average disease severity for the susceptible cultivars ranging from 4.4 at Lacombe in 1999 to 8.2 at Vegreville in 1998 (Table 5).

The results of the analysis of variance for groups 1 and 2 are presented in Tables 2 and 3, respectively. Since the interaction between location and accessions in group 1 was not significant, but the interaction between year and accession was significant, the three-way interaction between year, location, and the accessions was mainly attributed to the interaction between accession and year. No consistent trends were observed for the three-way interaction (data not presented). This indicated that pathotypes differentiated by the accessions were similar among sites, but the accessions responded differently over years due to variation in environmental conditions. Mean disease levels were highest in 1997 and lowest in 1999. Hudson had the lowest scald rating and was resistant at all locations and in all years (Table 1). Atlas, Atlas 46, Atlas 68, Abyssinian,
Kitchin, and Turk had relative severity values of $40 \%$ or less, indicating that the major genes in these accessions were effective against the predominant pathotypes in Alberta. Modoc and Trebi had intermediate disease severity levels ( $>60 \%)$.

For the commercial cultivars, all interactions among year (group 1 only), site, and cultivar were significant (Tables 3 and 4), indicating that cultivar reactions to scald were dependent on the presence of different pathotypes and environmental conditions among the test sites. Greenhouse inoculations reported in another study (22) confirmed that the scald reactions of commercial cultivars were different from those

Table 3. Results of analysis of variance for relative scald severity for homogeneous group 1 of bar-

\begin{tabular}{|c|c|c|c|c|c|c|c|}
\hline \multicolumn{4}{|c|}{ Accession group $1^{x}$} & \multicolumn{4}{|c|}{ Cultivar group $1^{y}$} \\
\hline Source & df & MS & $F^{\mathbf{z}}$ & Source & df & MS & $F^{\mathbf{z}}$ \\
\hline Year (Y) & 2 & 2,784 & 2.28 & Year (Y) & 2 & 969 & $3.10^{*}$ \\
\hline Location (L) & 7 & 6,250 & 2.98 & Location (L) & 7 & 2,945 & $9.60 * *$ \\
\hline $\mathrm{Y} \times \mathrm{L}$ & 4 & 3,235 & $7.31 * *$ & $\mathrm{Y} \times \mathrm{L}$ & 2 & 153 & $<1$ \\
\hline Rep in $Y, L$ & 45 & 276 & $1.72 * *$ & Rep in $\mathrm{Y}, \mathrm{L}$ & 39 & 561 & 4.56 ** \\
\hline Accession (A) & 7 & 15,610 & $3.58 *$ & Cultivar (C) & 32 & 6,274 & $6.30 * *$ \\
\hline $\mathrm{Y} \times \mathrm{A}$ & 14 & 1,559 & $4.42 * *$ & $\mathrm{Y} \times \mathrm{C}$ & 64 & 470 & $2.30 * *$ \\
\hline $\mathrm{L} \times \mathrm{A}$ & 49 & 481 & 1.40 & $\mathrm{~L} \times \mathrm{C}$ & 224 & 353 & $1.75 * *$ \\
\hline $\mathrm{Y} \times \mathrm{A} \times \mathrm{L}$ & 28 & 339 & $2.11 * *$ & $\mathrm{Y} \times \mathrm{C} \times \mathrm{L}$ & 64 & 202 & $1.65 * *$ \\
\hline
\end{tabular}
ley accessions and cultivars in field trials, Alberta, 1997 to 1999

${ }^{x}$ Includes 14 trials: Calmar 1997, Lacombe 1997, Stettler 1997, Trochu 1997, Edmonton 1997, Westlock 1997, Lacombe 1998, Stettler 1998, Trochu 1998, Vegreville 1998, Westlock 1998, Carstairs 1999, Calmar 1999, and Stettler 1999.

y Includes 12 trials: Calmar 1997, Lacombe 1997, Stettler 1997, Trochu 1997, Edmonton 1997, Westlock 1997, Lacombe 1998, Trochu 1998, Vegreville 1998, Calmar 1999, Carstairs 1999, and Stettler 1999.

$\mathrm{z} *$, ** significant at $P \leq 0.05$ or 0.01 , respectively.

Table 4. Results of analysis of variance for relative scald severity for homogeneous group 2 of bar-

\begin{tabular}{|c|c|c|c|c|c|c|c|}
\hline \multicolumn{4}{|c|}{ Accession group $2^{x}$} & \multicolumn{4}{|c|}{ Cultivar group $2^{y}$} \\
\hline Source & df & MS & $F^{\mathbf{z}}$ & Source & df & MS & $F^{\mathbf{z}}$ \\
\hline Location (L) & 3 & 4,945 & $8.29 * *$ & Location (L) & 5 & 24,286 & $32.44 * *$ \\
\hline Rep in L & 12 & 628 & 1.67 & Rep in $\mathrm{L}$ & 18 & 748 & $1.96 * *$ \\
\hline Accession (A) & 8 & 1,582 & $4.22 * *$ & Cultivar (A) & 32 & 4,066 & $10.68^{* *}$ \\
\hline $\mathrm{L} \times \mathrm{A}$ & 20 & 344 & $<1$ & $\mathrm{~L} \times \mathrm{C}$ & 160 & 850 & $2.23 * *$ \\
\hline
\end{tabular}
ley accessions and cultivars in field trials, Alberta, 1997 to 1999

x Includes four trials: Beaverlodge 1997, Carstairs 1997, Edmonton 1998, and Lacombe 1999.

y Includes six trials: Beaverlodge 1997, Carstairs 1997, Stettler 1998, Edmonton 1998, Westlock 1998, and Lacombe 1999.

$\mathrm{z} *, * *$ significant at $P \leq 0.05$ or 0.01 , respectively.

Table 5. Mean scald severity for the three susceptible cultivars and Shannon's information statistic

\begin{tabular}{|c|c|c|c|c|}
\hline Year & Site & $\begin{array}{l}\text { Mean severity of three } \\
\text { susceptible cultivars }^{x}\end{array}$ & $\begin{array}{l}\text { Resistance } \\
\text { status }^{\mathrm{y}}\end{array}$ & $\begin{array}{l}\text { Shannon's } \\
\text { statistic }^{\mathrm{z}}\end{array}$ \\
\hline 1997 & Beaverlodge & 4.8 & - & 0.074 \\
\hline 1997 & Calmar & 6.8 & + & 1.340 \\
\hline 1999 & Calmar & 5.3 & + & 1.104 \\
\hline 1997 & Carstairs & 5.8 & - & 1.247 \\
\hline 1999 & Carstairs & 5.3 & + & 1.064 \\
\hline 1997 & Edmonton & 7.8 & + & 1.339 \\
\hline 1998 & Edmonton & 5.5 & - & 0.095 \\
\hline 1997 & Lacombe & 6.9 & + & 1.305 \\
\hline 1998 & Lacombe & 6.5 & + & 1.169 \\
\hline 1999 & Lacombe & 4.4 & + & 1.150 \\
\hline 1997 & Trochu & 5.5 & + & 1.322 \\
\hline 1998 & Trochu & 4.9 & + & 1.354 \\
\hline 1997 & Stettler & 6.3 & - & 1.276 \\
\hline 1998 & Stettler & 6.3 & - & 1.105 \\
\hline 1999 & Stettler & 5.5 & - & 1.060 \\
\hline 1997 & Westlock & 5.6 & - & 1.079 \\
\hline 1998 & Westlock & 7.2 & - & 0.098 \\
\hline 1998 & Vegreville & 8.2 & + & 1.261 \\
\hline
\end{tabular}
for each test site and year

${ }^{\mathrm{x}}$ Mean disease severity of three susceptible cultivars, Argyle, Harrington, and Jackson, measured using a 0 to 9 scale.

${ }^{\mathrm{y}}$ - resistance held up; + resistance overcome in cultivars classified in the intermediate reaction group as determined by cluster analysis.

${ }^{z}$ Shannon's information statistic for phenotypic diversity. 
of the accessions used as differentials and that there were significant differences in pathotype frequency among locations.

At a distance of 1.4 for relative disease severity based on cluster analysis, the scald reaction of commercial cultivars can be classified into four major groups consisting of three resistant (R), nine moderately resistant (MR), six intermediate (I), and 14 moderately susceptible cultivars (MS) (Fig. 1, Table 2). The cultivars in each group were similar in scald reaction. Culti- vars AC Stacey, Kasota, and Seebe were grouped together with a mean of relative disease severity of $31 \%$ (Table 2). The MR, I, and MS groups joined each other at a distance level of 1.5 , and these three groups joined the $\mathrm{R}$ group at 2.5 (Fig. 1). This indicated that there was a greater difference in scald reaction between the resistant group and the remaining three groups, compared with differences among the MR, I, and MS groups. Cultivars in the MR group had a relative mean disease severity of $58 \%$. The majority of the commercial cultivars evaluated had intermediate to moderately susceptible reactions with relative mean disease severity values ranging from 69 to $82 \%$. In the intermediate group, a few cultivars, including CDC Earl at Trochu in 1997 and 1998, CDC Guardian at Lacombe in 1998, TR129 at Calmar in 1997 and 1999, at Trochu in 1997 and 1998, and at Lacombe in 1999, were as susceptible as the three susceptible cultivars, Argyle, Harrington, and Jackson (Table 2).

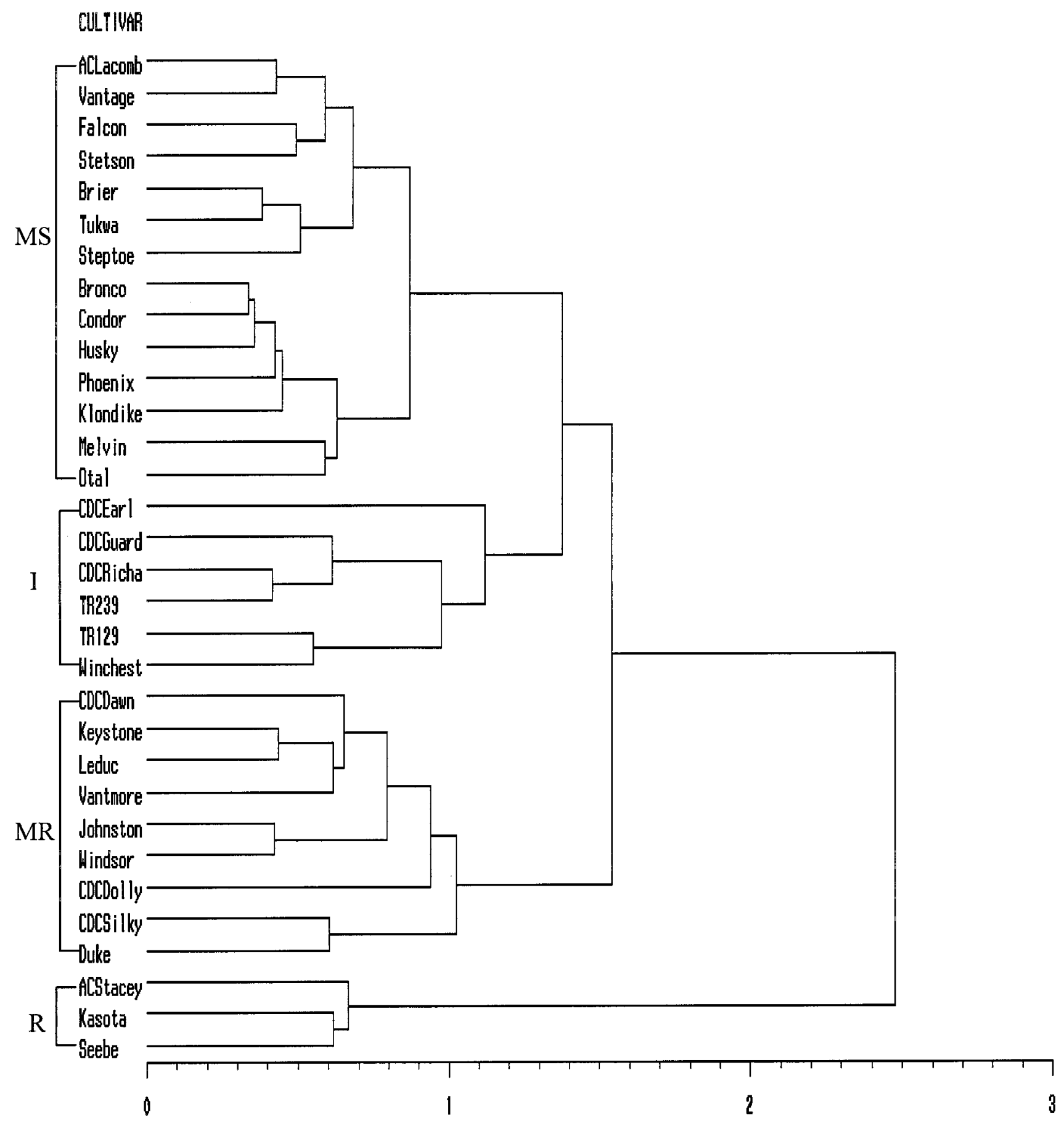

Maxinun Distance Between Clusters

Fig. 1. Hierarchical classification of 32 commercial barley cultivars based on relative scald severity in relation to the mean of three susceptible cultivars using the complete linkage method of cluster analysis. 
Cultivars in the intermediate group were first classified as resistant (1) when registered for commercial production and were similar in scald reaction to resistant cultivars, including AC Stacey, Kasota, and Seebe. However, cultivars in the intermediate group in the current study were subsequently found to have intermediate or susceptible reactions in commercial fields and small plot trials $(21,23)$. The reactions of the intermediate group were chosen to determine if the breakdown of resistance had occurred at a particular site. For each site and year, if the value for relative mean disease severity in the intermediate group was equal to or higher than the relative mean severity in the moderately susceptible group, cultivar resistance was considered to have been overcome as a result of the occurrence of new virulent pathotypes at that site and season. Based on this criterion, virulent pathotypes that attacked cultivars in the intermediate group occurred at Calmar in 1997 and 1999, Carstairs in 1998, Lacombe in 1997 to 1999, Trochu in 1997 and 1998, Vegreville in 1998, and Edmonton in 1997. Virulent pathotypes did not occur at Beaverlodge in 1997, Carstairs in 1997, Edmonton in 1998, Stettler in 1997 to 1999, or Westlock in 1997 and 1998 (Tables 2 and 5). Cultivars at Beaverlodge, Stettler, and Westlock showed no sign of resistance breakdown during the study period.

Based on disease reaction data, Shannon's information statistic indicated that on average from 1997 to 1999, populations of $R$. secalis at Beaverlodge, Stettler, and Westlock were less diverse than those at the other locations (Table 5). Phenotypic diversity of populations of $R$. secalis was greater at Edmonton and Westlock in 1997 compared with 1998, reflecting the difference in frequency and composition of $R$. secalis populations and the influence of environmental conditions.

\section{DISCUSSION}

The majority of test sites were established on land with scald-infested barley stubble and without artificial inoculation, which resembled conditions in commercial barley fields in Alberta. The host/pathogen system for barley/R. secalis was evaluated under conditions where the cultivars were likely exposed to multiple pathotypes, and where both qualitative and quantitative resistance genes, if present, were fully tested and expressed and adult plant resistance was able to be determined. The tests at multiple sites and seasons allowed comparison and determination of spatial and temporal variation in pathogen virulence under natural conditions that were similar to those for commercial barley production. Multi-season and -site tests can confound the effects of environment, as well as host, on the shifts in pathotypes of $R$. secalis. In the present study, only those sites with an average severity level greater than 4.4 for the mean rating for the three susceptible cultivars from the second assessment date were used for the analyses, which reduced the impact of environmental variation among sites by assuring that environmental conditions were conducive for scald development. In addition, the effects of environment and cultivars on pathotypes were estimated using the analysis of variance. The potential impact of the environment can also be removed by the use of artificial inoculation under controlled environmental conditions. A previous greenhouse study in which 256 isolates of $R$. secalis from the same sites and years used for the current study were inoculated on a set of differentials demonstrated that there were significant differences in pathotype diversity and complexity among locations in Alberta (22). Isolate virulence was most diverse at the Calmar site compared with the other sites. Edmonton and Lacombe were similar in pathogen variability, and these two sites were significantly more diverse compared with Beaverlodge, Carstairs, Stettler, and Westlock, which had the lowest diversity of pathotypes of $R$. secalis. Isolates at the Trochu and Vegreville sites had intermediate levels of diversity in virulence.

Based on restriction fragment length polymorphism (RFLP) markers, a population of 265 isolates of $R$. secalis from different locations in Australia differed significantly in allele frequency and genotype diversity (10). Similarly, gene flow among the populations of $R$. secalis sampled from Idaho and Oregon was considered to be limited because there was strong geographic differentiation among the pathotypes and in the virulence frequencies in different locations (8). No obvious relationship was observed between virulence pattern and geographic origin among 38 isolates from various areas of Denmark (9). It appears that the number of isolates used and the size of the geographic areas studied contributed to different results when determining the relationship between pathotype composition and geographic locations. Multiple infection cycles by $R$. secalis during a growing season are primarily through the production of splash-dispersed conidia (16). Scald develops mainly between adjacent plants, and infection loci occur several meters away from the source of inoculum (3). Splash-dispersed transmission tends to localize pathotype development compared with diseases with windborne inoculum, such as powdery mildew and rust (8).

Differences in scald reactions for commercial cultivars among locations, as indicated by significant interactions and the localization of pathotypes demonstrated in a previous greenhouse study (22), indicate an uneven distribution of pathotypes of $R$. secalis in Alberta. Consequently, the selection of cultivars grown by producers in a particular area may be important when trying to use disease resistance for scald management. For example, cultivars in the intermediate group should not be grown at Edmonton, Calmar, Carstairs, Lacombe, Trochu, or Vegreville, where virulent pathotypes that are able to overcome the resistance in these cultivars are present. Cultivars in the moderately resistant group also showed relatively high levels of scald at these sites, so crop rotation, where appropriate, also should be used to slow the appearance and increase of virulent pathotypes. These recommendations serve only as a general guide for scald management in Alberta. Monitoring of individual fields by producers will be important for determining which resistant cultivars are still effective against the pathotypes of $R$. secalis in their local area. Producers will need to consider using different sources of resistance where higher than expected disease levels are encountered in previously resistant cultivars.

The present study classified several western Canadian cultivars, including CDC Earl, CDC Guardian, TR123, and Winchester, into one cluster, indicating that the genetic basis for scald resistance in these western Canadian cultivars may be similar. These results are in agreement with those obtained by Penner et al. (12). In contrast, in the present study, Hudson and Atlas were resistant, but the four western Canadian cultivars, which were considered by Penner et al. (12) to be similar in scald reactions to Hudson, were intermediate to moderately susceptible. The discrepancy between the two studies may reflect the development of new pathotypes that caused differences in scald reactions. While there was similarity in scald reactions among barley cultivars between the present study and a study in 1993 (25), the cultivars CDC Earl, CDC Guardian, AC Lacombe, Brier, Falcon, and Tukwa were more susceptible in the present study. Most of these cultivars were registered for commercial production between 1991 and 1993, except for Brier, which was registered in 1988 (6). With the time needed to increase seed stocks, these cultivars were not widely available for commercial production for 2 to 3 years after registration. Thus, the resistance in most of these cultivars only remained effective for 1 to 4 years after being widely available for commercial production by farmers. Breakdown of resistance in newly released cultivars has also been observed in eastern Canada (26). Consequently, because of the rapid appearance of virulent pathotypes, it is necessary to monitor changes in the composition and frequency of pathotypes of $R$. secalis for breeders, pathologists, and farmers to effectively utilize the most resistant cultivars. The scald resistance in some accessions and cultivars has remained stable. For example, the resistance in Abyssinian, Hudson, Atlas 46, Atlas 68, Kitchin, Turk, AC Stacey, Kasota, and Seebe remained effective over all test sites 
and years. Other cultivars in the resistant and moderately resistant groups may also be useful for breeding durable resistance. For example, cv. Leduc has been shown to be tolerant to scald with minimum yield reductions over a 3-year field test (23), and CDC Dolly has been considered to possess a slow-scalding characteristic (18).

The diversity of pathogen virulence was determined using commercial cultivars instead of accessions. This was based on the consideration that the diversity of pathogen virulence is likely a function of the commercial cultivars that have been grown at a particular site. Calmar and Lacombe have been used at a barley breeding location and a scald nursery, respectively, where numerous barley genotypes have been planted and screened for resistance. Selection toward more pathotypes with complex virulence may have arisen at Calmar and Lacombe from unidentified resistance genes in the local cultivars and breeding lines. Trochu and Stettler have also been used as barley breeding sites, but received a half to two-thirds less rainfall compared with Calmar and Lacombe during the growing seasons of 1997 to 1999 (Environment Canada, data not presented). Virulent pathotypes occurred at Trochu that overcame cultivar resistance at this site, but not at Stettler during the course of this study. A preliminary study in 2000 and 2001 at Stettler showed that resistant cultivars, such as CDC Guardian and CDC Earl, tended to increase their level of susceptibility (K. Xi, unpublished data).

The population of $R$. secalis was more diverse at Edmonton in 1997 than in 1998, but the tests were conducted at different sites each season. The plots in 1997 were established on land where scald-infested barley stubble was retained, whereas those in 1998 were on the land without scaldinfested stubble. Thus, the substantial change in diversity at Edmonton likely reflected the difference in the potential number of pathotypes available for these two sites. Lower disease ratings on the resistant cultivars at Beaverlodge, Stettler, and Westlock likely indicated that these sites lacked many of the virulent pathotypes that were commonly found at other sites. These results were supported by a greenhouse study (22) in which four to eight pathotypes were identified at Beaverlodge, Stettler, and Westlock, but one pathotype that was only virulent on the susceptible cultivar Harrington predominated. Breakdown of cultivar resistance, as indicated by higher disease ratings, occurred at Calmar, Edmonton, Lacombe, Trochu, and Vegreville, where 9 to 16 pathotypes were identified that were virulent on up to 7 of 12 differentials (22). At the Carstairs site, where resistance appeared to be overcome based on scald reactions from the present study, only five pathotypes were identified in the previous study (22). Overall, the cultivar resistance that was evaluated tended to break down more readily at those sites where a greater diversity of pathotypes occurred. Shannon's information statistic was significantly correlated with mean percent relative disease severity for the 32 commercial cultivars $(r=0.83, P=0.01)$, suggesting that under the current test conditions, disease severity was a measure of the diversity of the populations of $R$. secalis.

The considerable variability of $R$. secalis in response to cultivar resistance in Alberta requires ongoing monitoring of the development and changes of pathotypes in commercial fields. Furthermore, as new cultivars are registered each year, the commercial cultivars evaluated in the present study may not represent the newer genotypes grown in Alberta. As a consequence, newly registered cultivars should be evaluated to update information on their scald reactions over a range of sites and years. Further studies using more accessions with additional genes may also be needed to facilitate ongoing assessment of pathotype variation and identification of novel sources of resistance.

\section{ACKNOWLEDGMENTS}

We gratefully acknowledge the technical assistance of C. Bos, D. Clark, E. Smith-Degenhardt, A. McCarty, A. Olson, D. Orr, N. Rauhala, D. Runge, K. Yaworsky, and the Gateway Research Organization. This study was partially funded by grants from the Alberta Barley Commission and the Alberta Agricultural Research Institute.

\section{LITERATURE CITED}

1. Anonymous 1996-2001. Varieties of cereals and oilseed crops for Alberta. Agdex 100/32. Alberta Agriculture, Food and Rural Development.

2. Anonymous 2000. Agriculture Statistics Year Book. Alberta Agriculture, Food and Rural Development. Online publication.

3. Ayesu-Offei, E. N., and Carter, M. V. 1971. Epidemiology of leaf scald of barley. Aust. J. Agric. Res. 22:383-390.

4. Buchannon, K. W., and Wallace, H. A. H. 1962. Note on the effect of leaf disease on yield, bushel weight and thousand-kernel weight of Parkland barley. Can. J. Plant Sci. 42:534-536.

5. Couture, L. 1980. Assessment of severity of foliage diseases of cereals in cooperative evaluation tests. Can. Plant Dis. Surv. 60:8-10.

6. Dyson, C. 2002. Field Crop Development Centre: Historical barley collection [online]. Alberta Agriculture, Food and Rural Development. Online publication, 29 September 2002.

7. Eyal, Z., Scharen, A. L., Huffman, M. D., and Prescott, J. M. 1985. Global insight into virulence frequency of Mycosphaerella graminicola. Phytopathology 75:1456-1462.

8. Goodwin, S. B., Allard, R. W., Hardy, A. S., and Webster, R. K. 1992. Hierarchical structure of pathogenic variation among Rhynchosporium secalis populations in Idaho and Oregon. Can. J. Bot. 70:810-817.

9. Jorgensen, H. J. L., and Smedegaard-Petersen, V. 1995. Pathogenic variation of Rhynchosporium secalis in Denmark and sources of resistance in barley. Plant Dis. 79:297-301.

10. McDonald, B. A., Zhan, J., and Burdon, J. J. 1999. Genetic structure of Rhynchosporium se calis in Australia. Phytopathology 89:639-645.

11. McLelland, M. B. 1989. Barley production in Alberta. Alberta Agriculture, Agdex 114/20-I. Edmonton, Alberta, Canada.

12. Penner, G. A., Tekauz, A., Reimer, E., Scoles, G. J., Rossnagel, B. G., Eckstein, P. E., Legge, W. G., Burnett, P. A., Ferguson, T., and Helm, J. H. 1996. The genetic basis of scald resistance in western Canadian barley cultivars Euphytica 92:367-374.

13. Petersen, R. G. 1994. Agricultural Field Experiments. Design and Analysis. Marcel Dekker, New York.

14. Saari, E. E., and Prescott, J. M. 1975. A scale for appraising the foliar intensity of wheat diseases. Plant Dis. Rep. 59:377-380.

15. Schaller, C. W., and Chim, C. I. 1969. Registration of Atlas 68 barley. Crop Sci. 9:521.

16. Shipton, W. A., Boyd, W. J. R., and Ali, S. M. 1974. Scald of barley. Rev. Plant Pathol. 53:839-861.

17. Skoropad, W. P. 1960. Barley scald in the prairie provinces of Canada. Commonw. Phytopathol. News 6:25-27.

18. Sorkhilalehloo, B., Tewari, J. P., Turkington, T. K., Capettini, F., Briggs, K. G., Rossnagel, B., and Singh, R. P. 2002. Genetics of slowscalding resistance in barley. (Abstr.) Can. J. Plant Pathol. In press

19. Tekauz, A. 1991. Pathogenic variation in Rhynchosporium secalis on barley in Canada. Can. J. Plant Pathol. 13:298-304.

20. Tekauz, A. 1995. Proposed differentials to assess variability in Rhynchosporium secalis and Pyrenophora teres. Rachis 14:63-71.

21. Turkington, T. K., Burnett, P. A., Briggs, K. G., and Xi, K. 1998. Screening for scald resistance for future Alberta barley varieties. Final report, Project \# 60-058, Alberta Barley Commission

22. Xi, K., Turkington, T. K., Helm, J. H., and Bos, C. 2002. Pathogenic variation of Rhynchosporium secalis in Alberta. Can. J. Plant Pathol. 24:176-183.

23. Xi, K., Xue, A. G., Burnett, P. A., Helm, J. H., and Turkington, T. K. 2000. Quantitative resistance of barley cultivars to Rhynchosporium secalis. Can. J. Plant Pathol. 22:221-227.

24. Xue, G., Burnett, P. A., and Helm, J. 1994. Severity of, and resistance of barley varieties to, scald and net blotch in central Alberta. Can. Plant Dis. Surv. 74:13-17.

25. Xue, G., Burnett, P. A., Helm, J. H., and Rossnagel, B. 1995. Variation in seedling and adult-plant resistance to Rhynchosporium secalis in barley. Can. J. Plant Pathol. 17:46-48.

26. Xue, G., Hall, R., and Falk, D. 1991. Pathogenic variation in Rhynchosporium secalis from southern Ontario. Plant Dis. 75:934-938.

27. Zadoks, J. C., Chang, T. T., and Konzak, C. F. 1974. A decimal code for growth stages of cereals. Weed Res. 14:415-421.

28. Zhang, Q., Webster, R. K., and Allard, R. W. 1987. Geographic distribution and association between resistance to four races of Rhynchosporium secalis. Phytopathology 77:352357. 